\begin{tabular}{c} 
Tersedia online di: http://ejournal-balitbang.kkp.go.id/index.php/bawal \\
e-mail:bawal.puslitbangkan@ gmail.com \\
BAWAL WIDYA RISET PERIKANAN TANGKAP \\
Volume 8 Nomor 2 Agustus 2016 \\
p-ISSN: 1907-8226 \\
e-ISSN: 2502-6410 \\
BAWAL \\
Nomor Akreditasi: 620/AU2/P2MI-LIPI/03/2015 \\
\hline \hline
\end{tabular}

\title{
BEBERAPA PARAMETER POPULASI IKAN PEDANG (Xiphias gladius) DI SAMUDERA HINDIA BAGIAN TIMUR
}

\section{POPULATION PARAMETERS OF SWORDFISH (Xiphias gladius) IN THE EASTERN INDIAN OCEAN}

\author{
Bram Setyadji ${ }^{* 1}$, I Wayan Arthana ${ }^{2}$ dan I Wayan Kasa ${ }^{3}$ \\ 1) Loka Penelitian Perikanan Tuna - Bali, Jl. Jl. Mertasari No. 140, Sidakarya, Denpasar Selatan, Bali. Indonesia \\ 2) Program Pascasarjana Universitas Udayana, Kampus Bukit Jimbaran, Kuta Selatan, Jimbaran, Badung, Kabupaten Badung, Bali \\ 3) Fakultas Perikanan dan Ilmu Kelautan Universitas Udayana, Kampus Bukit Jimbaran, Kuta Selatan, Jimbaran, Badung, \\ Kabupaten Badung, Bali \\ Teregistrasi I tanggal: 24 Februari 2016; Diterima setelah perbaikan tanggal: 26 Agustus2016; \\ Disetujui terbit tanggal: 30 Agustus2016
}

\begin{abstract}
ABSTRAK
Komposisi hasil tangkapan ikan berparuh (Istiophoridae dan Xiphiidae) menduduki peringkat kedua terbesar setelah tuna (Thunnus sp.) pada perikanan rawai tuna. Sekitar $90 \%$ jenis ikan berparuh yang di daratkan didominasi oleh ikan pedang (Xiphias gladius), yang mana merupakan hasil tangkap sampingan dari perikanan rawai tuna, terutama di Samudera Hindia bagian timur. Meskipun dikategorikan sebagai ikan dengan nilai ekonomis tinggi, akan tetapi studi mengenai parameter populasi untuk spesies ini masih terbatas, terutama di Indonesia. Penelitian ini bertujuan untuk menduga parameter pertumbuhan, laju mortalitas dan laju ekploitasi ikan pedang berdasarkan data ukuran panjang. Model pengkajian stok menggunakan data frekuensi panjang dipilih karena ketersediaan dan kemudahan pengambilan data tersebut dibandingkan dengan metode lainnya. Penelitian ini menggunakan data pemantau ilmiah tahun 2005 sampai dengan 2014 dan data pengamatan harian pendaratan tuna dan sejenisnya tahun 2002 sampai dengan 2014 di Samudera Hindia. Hasil penelitian menunjukkan pertumbuhan ikan pedang relatif cepat, terutama pada awal masa pertumbuhan dengan nilai $\mathrm{K}=0,12 /$ tahun, $\mathrm{t}_{0}=-0,76025$ tahun dan $\mathrm{L}^{\circ}=$ 302,4 cmFL. Nilai F (0,28/tahun) sedikit lebih besar daripada nilai M (0,24/tahun), yang berarti kematian ikan pedang lebih banyak disebabkan oleh penangkapan. Nilai E sebesar 0,55 mengindikasikan bahwa ikan pedang yang tertangkap oleh armada rawai tuna di Samudera Hindia berada pada kondisi optimum.
\end{abstract}

Kata Kunci: Ikan pedang; pertumbuhan; laju mortalitas; laju eksploitasi; Samudera Hindia

\section{ABSTRACT}

Billfishes (Istiophoridae and Xiphiidae) are the second largest catch in tuna longline fisheries. About 90\% of billfishes landed dominated by swordfish (Xiphias gladius) which was a by-catch from tuna longline fisheries, especially in eastern Indian Ocean. Despite of its high economic value, study on stock assessment for this species is limited, especially in Indonesia. The catch-at-size based stock assessment model was applied, to its availability and ease on collecting the data. The Objectives of this study are to estimate growth parameter, mortality rate and exploitation rate based on catch-at-size data. The primary data was obtained from scientific observer program from 2005 to 2014 and port sampling data from 2002 to 2014. The result showed that swordfish were relatively fast growth, especially on their early age $(K=0.12 /$ year $)$ with t0 estimated around -0.76 year and Linf about 302.4 $\mathrm{cmLJFL}$. The estimated of total mortality $(Z)$, natural mortality $(M)$ and fishing mortality $(F)$ from the model were 0.52/year, 0.24/year and 0.28/year respectively. The explitation rate of swordfish in the eastern Indian Ocean is on optimum level $(E=0.55)$.

Keywords: Swordfish; age; growth; mortality rate; exploitation rate; Indian ocean 


\section{PENDAHULUAN}

Hasil tangkapan ikan berparuh (Istiophoridae dan Xiphiidae) menempati urutan kedua terbesar setelah tuna, dimana terkadang tidak tercatat dengan baik di logbook (Cramer et al., 1998). Hampir 90\% ikan berparuh yang di daratkan di dunia merupakan hasil tangkap sampingan dari perikanan rawai tuna (Prager et al., 1995; Amande et al., 2008, 2010; Chapman, 2001; Cramer \& Adams, 1999; Campbell \& Tuck, 1998). Ikan pedang (Xiphias gladius) merupakan satu-satunya spesies dari famili Xiphiidae dan telah menjadi obyek eksploitasi di Samudera Pasifik (Brodziak \& Ishimura, 2010), Atlantik, dan Laut Mediterania (Tserpes \& Tsimenides, 1995). Di Samudera Hindia, eksploitasi ikan pedang, dimulai sejak tahun 1950an oleh armada Jepang dan didominasi oleh armada Taiwan pada tahun 1990-an (IOTC, 2009) sedangkan Indonesia mulai pada tahun 1983 semenjak diperkenalkannya deep tuna longline (Sadiyah et al., 2011). Hasil tangkapan ikan pedang di Samudera Hindia terus meningkat, sekitar 10.000 ton pada awal tahun 1990 dan mencapai puncaknya pada tahun 1998, yakni sekitar 35.000 ton (Wang \& Nishida, 2010). Kontribusi ikan pedang terhadap perikanan tuna di Indonesia pada kurun waktu 2004-2007 sekitar 6.400 ton, dengan rata - rata produksi mencapai 1.600 ton (Mahiswara \& Prisantoso, 2009) setara dengan 1\% dari produksi nasional yang berasal dari Samudera Hindia (Irianto et al., 2015).

Seiring dengan tingkat eksploitasi yang terus meningkat, sumberdaya ikan pedang di Samudera Hindia terus menurun, indikatornya adalah penurunan CPUE (Catch per Unit of Effort) secara global dari tahun ke tahun dengan tingkat laju eksploitasi sudah mencapai padat tangkap (fully exploited) (IOTC, 2009). Kondisi tersebut menunjukkan bahwa jumlah penangkapan sudah mendekati nilai maksimum tangkapan lestarinya (MSY) yakni antara $29.900-34.200$ ton (IOTC, 2014). Untuk menghindari adanya penangkapan yang berlebih maka dibutuhkan upaya pengelolaan ikan pedang yang optimal, sehingga sumberdaya ikan pedang dapat dimanfaatkan secara berkelanjutan.

Penelitian mengenai dinamika populasi ikan peruaya jauh terutama di Samudera Hindia pada umumnya menggunakan model yang rumit dan melibatkan banyak variabel, sehingga tidak semua negara dapat melakukan kajian yang komprehensif. Beberapa pendekatan ataupun model yang digunakan untuk menganalisa dinamika populasi ikan pedang adalah program FISAT (Gayanilo et al., 2005), ELEFAN (Gayanilo \& Pauly, 1989) dan LFSA (Sparre \& Venema, 1999).

Model - model tersebut menggunakan data biologi dengan frekuensi panjang sebagai basis analisanya. Data tersebut digunakan karena paling banyak tersedia dan mudah didapatkan dibandingkan data pengukuran jaringan keras (sisik, otolith, sirip dan tulang belakang) dan tagging (Pauly, 1984).

Dasar pemikiran dari Model tersebut adalah jika "terlalu sedikit ikan tua" maka stok sudah "lebih tangkap" dan tekanan penangkapan terhadap stok tersebut harus dikurangi, begitu juga sebaliknya apabila "terlalu banyak ikan tua" maka stok masih underfished dan masih lebih banyak lagi ikan yang dapat ditangkap untuk memaksimalkan hasil (Sparre \& Venema, 1999).

Penelitian ini menggunakan data frekuensi panjang sebagai basis analisa, yang mana selanjutnya akan digunakan untuk menduga umur dan pertumbuhan ikan pedang. Hasil dari pendugaan tersebut akan digunakan untuk menghitung laju mortalitas alami dan penangkapan sehingga didapatkan tingkat laju eksploitasi. Hasil penelitian ini diharapkan dapat digunakan sebagai masukan dalam studi kajian stok ikan pedang di masa yang akan datang.

\section{BAHANDANMETODE}

Penelitian ini menggunakan data pengamatan harian penangkapan ikan tuna dan sejenisnya pada kurun waktu 2002 - 2014 yang berbasis di Pelabuhan Benoa dan data pemantau ilmiah pada kurun waktu 2005 - 2014. Sebagian besar daerah penangkapan berada di sebelah selatan lintang $13^{\circ} \mathrm{LS}$, yang merupakan perairan laut bebas karena sudah di luar Zona Ekonomi Esklusif (ZEE) Indonesia. Spesimen ikan pedang yang digunakan untuk penelitian diperoleh dari hasil tangkapan kapal - kapal rawai tuna Indonesia (Gambar 1), yang berbasis di Pelabuhan Benoa, Pelabuhan Perikanan Nusantara (PPN) Palabuhanratu dan Pelabuhan Perikanan Samudera (PPS) Cilacap oleh 


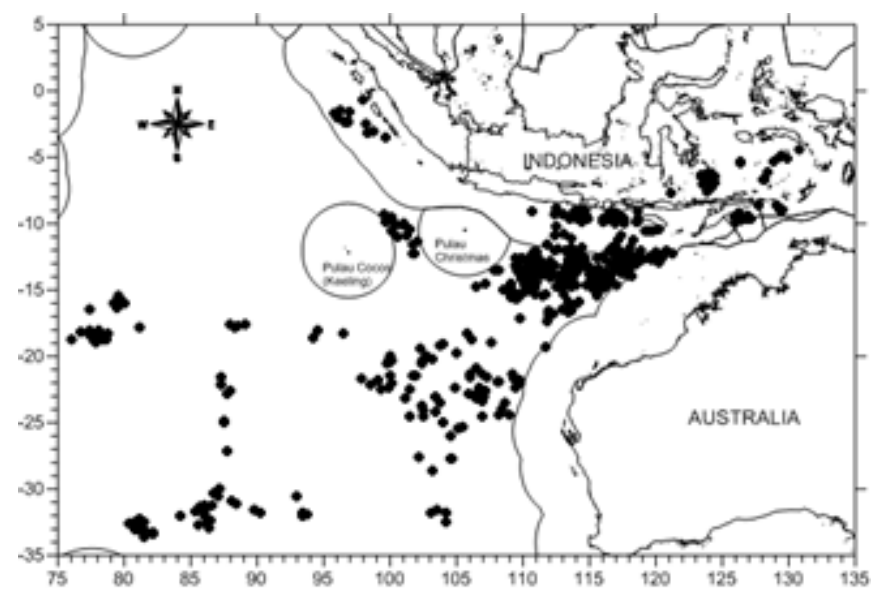

Gambar 1. Peta daerah penelitian. (Keterangan: bulatan hitam menunjukkan lokasi penangkapan ikan pedang sedangkan garis tipis di luar batas negara merupakan Zona Ekonomi Esklusif (ZEE)).

Figure 1. Map of research area. (Remarks: black circles show the fishing ground of swordfish and thin lines outside country border are EEZ).

pemantau ilmiah yang berasal dari Loka Penelitian Perikanan Tuna.

Pengukuran panjang ikan pedang di atas kapal dengan cara merentangkan pita pengukur di sepanjang tubuh ikan (pengukuran melengkung) dari ujung rahang bawah ke ujung lekukan tengah sirip ekor (LJFL/Lower Jaw Fork Length), sedangkan cara pengambilan ukuran panjang di darat biasanya dilakukan secara tegak lurus dengan menggunakan alat ukur yang sifatnya kaku (rigid), seperti: kaliper (pengukuran lurus). Karena ikan pedang yang didaratkan sudah diproses (potong kepala, sirip, disiangi isi perut dan insangnya) maka pengukuran panjang dilakukan dari dari pangkal sirip dada ke ujung lekukan tengah sirip ekor (PFL/Pectoral Fork Length). Data panjang ikan distandarisasi melalui persamaan regresi linear mengacu pada Setyadji et al. (2014).

Analisis data untuk mengetahui parameter pertumbuhan ikan dilakukan dengan menggunakan FiSAT II, program ELEFAN salah satu modul yang terdapat dalam perangkat lunak FiSAT II versi 1.2.2, yang menggunakan data frekuensi panjang. Persamaan yang digunakan oleh ELEFAN adalah rumus standar Von Bertalanffy Growth Function (Sparre \& Venema, 1999), yakni:

$$
L t=L_{\infty}\left(1-e^{-K(t-10)}\right)
$$

Dimana,

Lt : panjang pada umur $\mathrm{t}$

Lo: panjang asimtotik

$\mathrm{K}$ : koefisien pertumbuhan

$\mathrm{t}$ : waktu yang dibutuhkan untuk mencapai panjang tertentu

$\mathrm{t}_{0}$ : umur teoritis pada saat panjang sama dengan 0.
Umur teoritis ikan pada saat panjang sama dengan nol $\left(=\mathrm{t}_{\mathrm{o}}\right)$ dapat diduga secara terpisah menggunakan persamaan empiris Pauly (1984) sebagai berikut.

$\left.\log \left(-t_{0}\right)=0,3922-0,2752\left(\log L_{\infty}\right)-1,038(\log K) \ldots . . .2\right)$

Nilai Z pada penelitian ini menggunakan pendekatan kurva hasil tangkapan yang dikonversikan ke panjang (length-converted catch curve) yang diperkenalkan oleh Pauly (1990) dengan asumsi bahwa rekruitmen dianggap tetap selama waktu pengamatan (Punt et al., 2013). Pada dasarnya, length-converted catch curve merupakan plot persamaan regresi linear dimana slope/kemiringan $b$ diasumsikan menjadi nilai $\mathrm{Z}$.

$\ln (N / \Delta t)=a+b t^{\prime}$

Dimana,

$\mathrm{N}=$ jumlah ikan pada kelas panjang yang diberikan,

$\Delta \mathrm{t}=$ waktu yang dibutuhkan ikan untuk tumbuh pada kelas panjang yang tersebut

$\mathrm{a}=$ intersep

$\mathrm{t}^{\prime}=$ rata-rata umur (relatif) ikan pada kelas panjang tersebut.

Koefisien mortalitas alami (M) menggunakan persamaan empiris Pauly (1984), di mana:

$\log (M)=-0,0066-0,279 \log (\operatorname{L} \infty)+0,654 \log (K)+0,4634$

$\log (\mathrm{T})$

dimana:

$\mathrm{M}=$ mortalitas alami

$\mathrm{L} \infty=$ panjang asimtotik

$\mathrm{K}=$ koefisien pertumbuhan 
$\mathrm{T}=$ asumsi suhu rata-rata perairan di Samudera Hindia bagian timur sebesar $28,56^{\circ} \mathrm{C}$ (Yuniarti et al., 2013).

Berdasarkan hasil penghitungan kedua parameter tersebut, maka nilai kematian akibat penangkapan $(\mathrm{F})$ dapat ditentukan, dengan persamaan:

$\mathrm{F}=\mathrm{Z}-\mathrm{M}$

Laju eksploitasi (E) ditentukan dengan membandingkan laju mortalitas penangkapan (F) dengan laju mortalitas total (Z) (Pauly 1984):

$\mathrm{E}=\frac{\mathrm{F}}{\mathrm{F}+\mathrm{M}}=\frac{\mathrm{F}}{\mathrm{Z}}$

Sebuah stok akan dikatakan dalam kondisi lebih tangkap atau tidak berdasarkan asumsi nilai optimal $\mathrm{E}\left(\mathrm{E}_{\mathrm{opt}}\right)$ $\approx 0,5$. Asumsi ini juga berarti bahwa hasil yang berkelanjutan akan diperoleh ketika nilai $\mathrm{F} \approx \mathrm{M}$ (Gulland, 1971).

\section{HASIL DAN BAHASAN}

Hasil

Berdasarkan non-parametric scoring of VBGF fit (Rn) menggunakan Electronic Length Frequency Analysis (ELEFAN) I yang terdapat pada program FiSAT II, diketahui berdasarkan data frekuensi panjang ikan pedang pada kurun waktu 2002-2014 didapatkan nilai koefisien pertumbuhan $(\mathrm{K})=0,12$ per tahun dengan nilai $\mathrm{Rn}=0,134$; panjang asimtotik $(\mathrm{L} \infty)=302,4 \mathrm{~cm}$ dan nilai $\mathrm{t}_{0}=-0,76$ tahun. Nilai koefiesien pertumbuhan (K) sebesar 0,12 menujukkan bahwa ikan pedang bertipe slow growth dengan laju pertumbuhan 0,12/tahun. Panjang asimtotik (Lo) sebesar $302,4 \mathrm{~cm}$ artinya bahwa secara teoritis panjang ikan pedang berhenti tumbuh pada ukuran tersebut walaupun umurnya terus bertambah. Sedangkan nilai $\mathrm{t}_{\mathrm{o}}=-0,76$ artinya bahwa umur ikan pedang (semu) atau secara teoritis pada panjang $0 \mathrm{~cm}$ diduga sebesar -0,76 tahun.

Ketiga parameter pertumbuhan tersebut kemudian disubstitusikan ke persamaan von Bertalanffy sehingga didapatkan hasil $\mathrm{L}_{\mathrm{t}}=302,4\left(1-\mathrm{e}^{-0,12(t+0,760245)}\right)$, yang kemudian dilakukan kalkulasi mundur untuk mengetahui grafik perbandingan umur dan pertumbuhan ikan pedang (Gambar 2). Grafik tersebut menujukkan bahwa secara teoritis ikan pedang membutuhkan waktu 30 tahun lebih untuk mencapai panjang asimtotiknya. Pertumbuhan cepat di awal-awal tahun (4-6 tahun pertama) kemudian melambat pada tahun-tahun berikutnya.

Berdasarkan nilai $\mathrm{K}$ dan $\mathrm{L}$,yang diperoleh dari ELEFAN I maka nilai $\mathrm{M}$ (mortalitas alami) dapat dicari dengan menggunakan persamaan empiris Pauly (1984). Dari perasamaan tersebut didapatkan nilai mortalitas alami sebesar 0,24/tahun dengan asumsi suhu rata-rata perairan Samudera Hindia bagian timur sebesar $28,56^{\circ} \mathrm{C}$. Dengan menggunakan metode length-converted catch curve yang terdapat pada FISAT II, maka didapatkan nilai mortalitas total (Z) sebesar 0,52/tahun, sehingga nilai mortalitas akibat penangkapan (F) sebesar 0,28/tahun (Gambar 3). Laju mortalitas akibat penangkapan pada penelitian ini sedikit lebih besar daripada laju mortalitas alaminya, hal ini menunjukkan bahwa faktor kematian ikan pedang lebih besar disebabkan oleh kegiatan penangkapan.

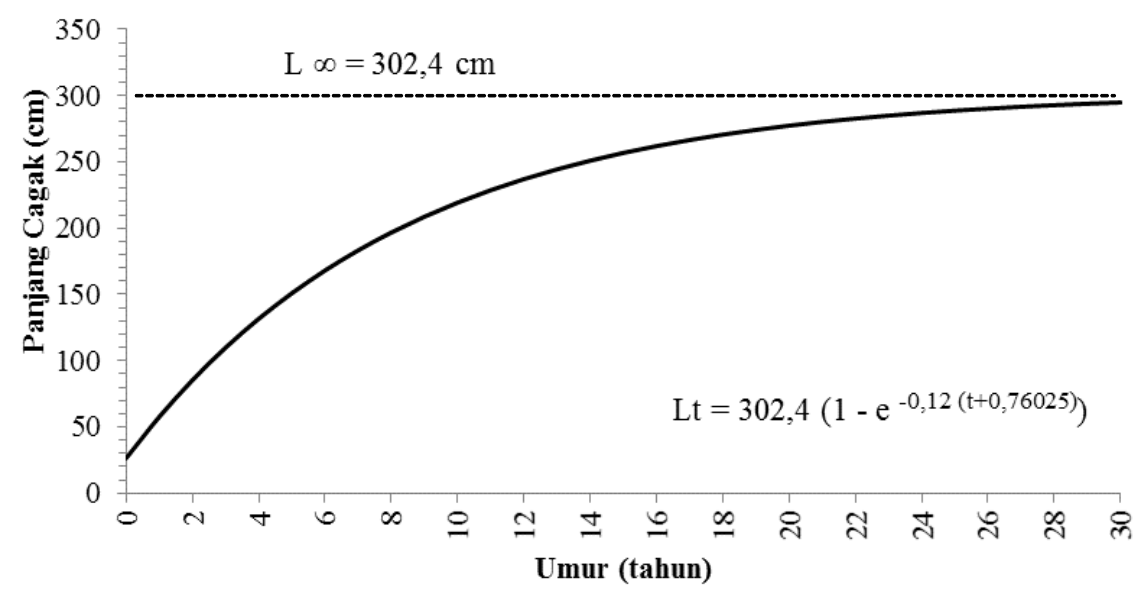

Gambar 2. Kurva pertumbuhan von Bertalanffy ikan pedang yang tertangkap oleh armada rawai tuna di Samudera Hindia dalam kurun waktu 2002-2014.

Figure 2. Von Bertalanffy growth curve of swordfish caught by Indonesian longliners in Indian Ocean during 2002-2014. 
Laju eksploitasi ikan pedang (E) didapatkan dengan cara membagi antara nilai $F$ (mortalitas akibat penangkapan) dan Z (nilai mortalitas total), yakni sebesar 0,55/tahun. Hal ini berarti 55\% kematian ikan pedang di perairan Samudera Hindia disebabkan oleh aktifitas penangkapan. Nilai tersebut juga berarti bahwa laju eksploitasi ikan pedang sudah mencapai nilai optimum/ padat tangkap karena nilai $\mathrm{EH} \approx 0,5$.

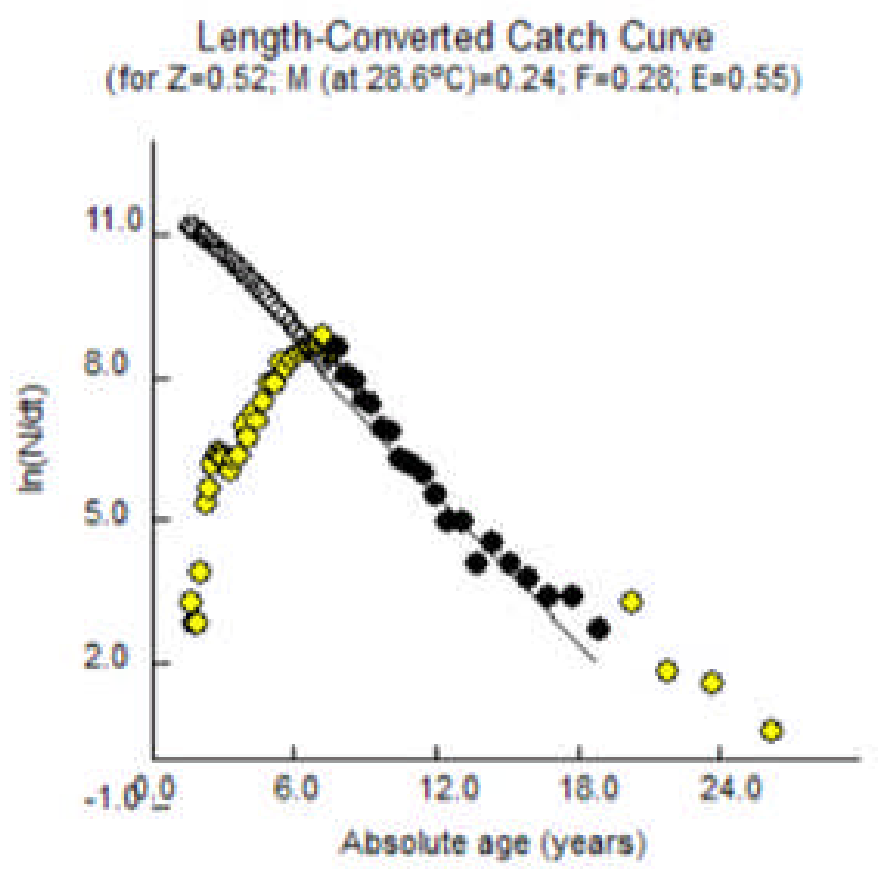

Gambar 3. Kurva hasil tangkapan yang dikonversikan ke panjang untuk menduga nilai mortalitas yang dihitung dari parameter persamaan pertumbuhan von Bertalanffy pada suhu rata-rata $28,6^{\circ} \mathrm{C}$. (Keterangan: $\mathrm{Z}=$ mortalitas total; $\mathrm{M}=$ mortalitas alami; $\mathrm{F}=$ mortalitas akibat penangkapan; $\mathrm{E}=$ tingkat laju eksploitasi; titik hitam= titik data dalam kurva yang digunakan dalam regresi).

Figure 3. Length-converted catch curve for estimating mortality rate calculated based on von Bertalanffy growth curve at average temperature $28.6{ }^{\circ} \mathrm{C}$. (Remarks: $Z=$ total mortality; $M=$ natural mortality; $F=f i s h i n g$ mortality; E=exploitation rate; black dots=data used for regression).

\section{Bahasan}

Ikan pedang mempunyai tipe pertumbuhan yang lambat, akan tetapi bisa tumbuh dengan cepat terutama di awal-awal tahun perkembangannya (Ehrhardt, 1992). Dalam penelitian ini ikan pedang dapat mencapai panjang $57,58 \mathrm{~cm}$ hanya dalam waktu 1 tahun (Gambar 2). Bahkan pada penelitian sebelumnya dilaporkan dapat tumbuh sepanjang $74 \mathrm{~cm}$ pada enam bulan pertama (Megalofonou et al., 1995) dan 90 - $100 \mathrm{~cm}$ pada umur satu tahun (Sun et al., 2010; Young \& Drake, 2004). Nilai koefisien pertumbuhan dalam penelitian ini $(0,12 /$ thn $)$ sedikit lebih kecil dibandingkan dengan Varghese et al. (2013) di perairan Laut India dan Wang et al. (2010) di barat dan timur Samudera Hindia. Model dalam penelitian ini tidak diverifikasi dengan model-model lain yang lebih dapat diandalkan, seperti penghitungan lingkaran tahun pada sirip anal maupun otolith, meskipun demikian estimasi nilai $\mathrm{K}$ dan Lo yang diberikan tidak berbeda jauh dengan penelitian-penelitian sebelumnya pada spesies yang sama (Tabel 1).
Nilai laju mortalitas alami (M) pada penelitian ini sebesar 0,24/tahun (Gambar 3), sedikit lebih tinggi daripada di perairan Chili sebesar 0,123/tahun (Barbieri et al.,1998) dan kepulauan Hawaii yakni sebesar masing-masing 0,20/ tahun, 0,21/tahun (Yabe et al., 1959; Uchiyama et al.,1998). Sedangkan Griggs et al. (2005) di Perairan Selandia Baru menggunakan persamaan Hoenig untuk menentukan nilai $\mathrm{M}$, dimana hasilnya tidak jauh berbeda yakni berkisar antara $0,21-0,28 /$ tahun dengan estimasi terbaik sebesar $0,2 /$ tahun.

Konsep dasar pengelolaan perikanan yang berkelanjutan adalah melalui pendekatan kehati-hatian (precautionary approach), dalam penelitian ini parameter yang digunakan adalah laju mortalitas. Secara teoritis nilai $\mathrm{F}$ bisa didapatkan dengan cara mengurangkan nilai mortalitas total $(Z)$ dengan nilai $M$. Nilai Z sebesar 0,52/ tahun, sehingga nilai mortalitas akibat penangkapan $(F)$ sebesar 0,28/tahun (Gambar 3). Nilai mortalitas akibat penangkapan yang lebih tinggi daripada nilai kematian alaminya menunjukkan bahwa tekanan penangkapan/ eksploitasi pada spesies ini cukup tinggi. 
Tabel 1. Hasil beberapa penelitian mengenai umur dan pertumbuhan ikan pedang.

Table 1. Results of selected studies on the growth of swordfish.

\begin{tabular}{|c|c|c|c|c|c|c|}
\hline $\begin{array}{l}\mathbf{L}_{\infty} \\
(\mathbf{c m})\end{array}$ & $\begin{array}{c}\mathrm{K} \\
(1 / \text { thn })\end{array}$ & $\mathbf{t}_{\mathbf{0}}$ & $\begin{array}{c}\text { Jenis } \\
\text { Kelamin } \\
(\text { Sex })\end{array}$ & $\begin{array}{l}\text { Metode } \\
\text { (Methods) }\end{array}$ & $\begin{array}{l}\text { Lokasi } \\
\text { (Location) }\end{array}$ & $\begin{array}{c}\text { Acuan } \\
\text { (References) }\end{array}$ \\
\hline 252,196 & 0,133 & $-2,432$ & Campur & Sirip anal & Laut Aegean & Aliçli \& Oray, 2001 \\
\hline 283,600 & 0,150 & $-2,090$ & Campur & Sirip anal & $\begin{array}{l}\text { Sebelah timur Laut } \\
\text { Mediterania }\end{array}$ & Akyol \& Ceyhan, 2013 \\
\hline 263,500 & 0,119 & $-2,270$ & Betina & Sirip anal & $\begin{array}{l}\text { Sebelah barat Laut } \\
\text { Mediterania }\end{array}$ & Valeiras et al., 2008 \\
\hline 185,500 & 0,219 & $-1,968$ & Jantan & Sirip anal & $\begin{array}{l}\text { Sebelah barat Laut } \\
\text { Mediterania }\end{array}$ & Valeiras et al., 2008 \\
\hline 321,000 & 0,133 & $-2,460$ & Betina & Sirip anal & Chili & Cerna, 2006 \\
\hline 279,000 & 0,158 & $-2,650$ & Jantan & Sirip anal & Chili & Cerna, 2006 \\
\hline 300,660 & 0,040 & $-0,750$ & Betina & Sirip anal & Taiwan & Sun et al., 2010 \\
\hline 213,050 & 0,086 & $-0,626$ & Jantan & Sirip anal & Taiwan & Sun et al., 2010 \\
\hline 227,200 & 0,534 & $-2,410$ & Betina & Sirip anal & Hawai & DeMartini, 2007 \\
\hline 221,000 & 0,070 & $-0,150$ & Jantan & Sirip anal & Hawai & DeMartini, 2007 \\
\hline 296,000 & 0,080 & $-3,700$ & Betina & Sirip anal & Australia & Young \& Drake, 2004 \\
\hline 224,200 & 0,130 & $-3,000$ & Jantan & Sirip anal & Australia & Young \& Drake, 2004 \\
\hline 576,600 & 0,033 & $-4,550$ & Campur & Sirip Anal & Selandia Baru & Griggs et al., 2005 \\
\hline 434,700 & 0,053 & $-3,460$ & Betina & Sirip anal & Selandia Baru & Griggs et al., 2005 \\
\hline 394,400 & 0,044 & $-5,860$ & Jantan & Sirip anal & Selandia Baru & Griggs et al., 2005 \\
\hline 274,855 & 0,138 & $-1,998$ & Betina & Sirip anal & $\begin{array}{l}\text { Timur Laut dan Barat } \\
\text { Laut Samudera } \\
\text { Hindia }\end{array}$ & Wang et al., 2010 \\
\hline 234,002 & 0,169 & $-2,181$ & Jantan & Sirip anal & $\begin{array}{l}\text { Sebelah Utara } \\
\text { Samudera Hindia }\end{array}$ & Wang et al., 2010 \\
\hline 311,110 & 0,170 & $-0,530$ & Betina & $\begin{array}{l}\text { Frekuensi } \\
\text { Panjang }\end{array}$ & $\begin{array}{l}\text { Perairan sekitar Laut } \\
\text { India }\end{array}$ & Varghese et al., 2013 \\
\hline 243,790 & 0,220 & $-0,370$ & Jantan & $\begin{array}{l}\text { Frekuensi } \\
\text { Panjang }\end{array}$ & $\begin{array}{l}\text { Perairan sekitar Laut } \\
\text { India }\end{array}$ & Varghese et al., 2013 \\
\hline 302,400 & 0,120 & $-0,760$ & Campur & $\begin{array}{l}\text { Frekuensi } \\
\text { Panjang }\end{array}$ & $\begin{array}{l}\text { Sebelah timur } \\
\text { Samudera Hindia }\end{array}$ & Studi ini (Present study) \\
\hline
\end{tabular}

Berdasarkan nilai $\mathrm{F}$ dan $\mathrm{M}$ yang telah diketahui maka didapatkan nilai laju eksploitasi (E) sebesar 0,55. Hal ini berarti tingkat laju eksploitasi ikan pedang di Samudera Hindia berdasarkan hasil tangkapan armada rawai tuna Indonesia berada pada kondisi padat tangkap (fully exploited) akan tetapi belum berada pada kondisi lebih tangkap. Hasil ini sesuai dengan hasil kajian yang dilakukan oleh IOTC (2014) yang menggunakan titik acuan MSY sebagai dasar model yang digunakan. Status stok ikan pedang di Samudera Hindia tidak berada pada kondisi lebih tangkap dan tidak menjadi subyek eksploitasi yang berlebih, walaupun terjadi penurunan hasil tangkapan di sebelah barat Samudera Hindia. 
Walupun kondisi stok ikan pedang belum menjadi subyek eksploitasi yang berlebih akan tetapi tingkat laju eksploitasi berada pada kondisi padat tangkap sehingga potensi terjadinya kondisi lebih tangkap sangat tinggi terutama beberapa tahun mendatang. Permasalahan yang dihadapi adalah ikan merupakan hasil tangkapan sampingan dari perikanan rawai tuna, sehingga pengelolaannya lebih sulit untuk dilakukan. Salah satu cara yang dapat dilakukan adalah membatasi ataupun moratorium ijin baru untuk kapal rawai tuna, mengingat total armada rawai tuna Indonesia yang terdaftar di IOTC per 26 Desember 2014 cukup besar yakni sebanyak 1.282 unit, dengan komposisi armada di atas 30 GT sebesar 1.040 unit $(81,20 \%)$ (Irianto et al., 2014), dengan adanya Peraturan Menteri Kelautan dan Perikanan Republik Indonesia Nomor 56/PERMEN-KP/2014 tentang penghentian sementara (moratorium) perizinan usaha perikanan tangkap di wilayah pengelolaan perikanan negara Republik Indonesia maka akan mempertahankan upaya penangkapan, bahkan isi peraturan tersebut mencakup moratorium perpanjangan izin yang telah habis masa berlakunya, sehingga diharapkan selama moratorium berlaku sumberdaya ikan pedang dapat pulih kembali.

\section{KESIMPULAN}

Ikan pedang tergolong ikan berumur panjang dengan kecepatan pertumbuhan yang tinggi pada awal-awal tahun perkembangannya. Laju kematian ikan ini diduga lebih banyak disebabkan oleh eksploitasi/penangkapan. Tingkat eksploitasi ikan pedang yang tertangkap oleh armada rawai tuna di Samudera Hindia telah berada pada kondisi optimum (padat tangkap).

\section{PERSANTUNAN}

Penulis mengucapkan terima kasih kepada Dian Novianto, Andi Bahtiar, Yusuf Affandi, Ashadi, Adi Subagio, Irwan Jatmiko, Hasan Syaiful Rizal, Hefi Sukardianto, Gede, dan rekan rekan semuadari Loka Penelitian Perikanan Tuna yang telah bekerja keras mengumpulkan data untuk penyusunan makalah ini. Penghargaan juga diberikan kepada Commonwealth Scientific and Industrial Research Organisation (CSIRO), Australian Centre for International Agricultural Research (ACIAR) dan Pusat Penelitian Pengelolaan Perikanan dan Konservasi Sumber Daya Ikan (P4KSI) yang telah mendukung dan mendanai kolaborasi penelitian melalui program FIS/2002/074: Capacity Development to Monitor, Analyse and Report on Indonesian Tuna Fisheries.

\section{DAFTAR PUSTAKA}

Aliçli, T.Z. \& Oray, I.K. (2001). Age and growth of swordfish (Xiphias gladius L., 1758) in the Eastern Mediterranean Sea. Col. Vol. Sci. Pap. ICCAT. 52(2), 698-707.

Barbieri, M.A., Canales, C., Correa, V., Donoso, M., Casanga, A.G., Leiva, B., Montiel, A., \& Yáñez, E. (1998). Development and present satate of the swordfish, Xiphias gladius, fishery in Chile. NOAA technical Report NMFS. 142, 1-10

Brodziak, J. \& Ishimura, G. (2010). Stock assessment of North Pacific swordfish (Xiphias gladius) in 2009. Pacific Islands Fish. Sci. Cent., Natl. Mar. Fish. Serv., NOAA, Honolulu, HI 96822-2396. Pacific Islands Fish. Sci. Cent. Admin. Rep. H-10-01. p. 37.

Campbell, R.A., \& Tuck, G.N. (1998). Preliminary analysis of billfish catch rates in the Indian Ocean. $7^{\text {th }}$ Expert Consultation on Indian Ocean, Victoria, Seychelles, 914 November 1998: p. 19.

Cerna, J.F. (2006). Age and growth of the swordfish (Xiphias gladius Linnaeus, 1758) in the southeastern Pacific off Chile. Lat. Am. J. Aquat. Res. p.11.

Chapman, L. (2001). Bycatch in the tuna longline fishery. $2^{\text {nd }}$ SPC Heads of Fisheries Meeting (Noumea, New Caledonia, 23-27 July 2001).

Cramer, J., \& Adams, H.M. (1999). Pelagic longline bycatch. Col. Vol. Sci. Pap. ICCAT. 49(4), 288-299.

Cramer, J., Bertolino, A., \& Scott, G.P. (1998). Estimates of recent shark bycatch by U.S. vessels fishing for Atlantic tuna and tuna-like species. Col. Vol. Sci. Pap. ICCAT. 48(3), 117-128.

DeMartini, E. E., Uchiyama, J.H., Humphreys Jr, R. L., Sampaga, J.D., \& Williams, H.A. (2007). Age and growth of swordfish (Xiphias gladius) caught by the Hawaii-based pelagic longline fishery. Fish. Bull. 105, 356-367.

Ehrhardt, N. M. (1992). Age and growth of swordfish, Xiphias gladius, in the northwestern Atlantic. Bull. Mar. Sci. 50(2), 292"301.

Gayanilo, F.C., \& D. Pauly. (1989). Announcing the release of Version 1.1 of the Complete ELEFAN Software package. Fishbyte. 7(2), 20-21.

Gayanilo, F.C., Sparre, P., \& Pauly, D. (2005). FAOICLARM Stock Assessment Tools II (FISAT II). Revised version. User's guide. FAO Computerized Information Series (Fisheries). (8). 
Griggs, L., Francis, M., \& Maolagáin, C. Ó. (2005). Growth rate, age at maturity, longevity and natural mortality rate of swordfish (Xiphias gladius). New Zealand Fisheries Assessment report 2005/56: p. 29.

Gulland, J.A. (1971). The Fish Resources of the Oceans. FAO Fishing News Books, Ltd., Surrey, England.

IOTC (Indian Ocean Tuna Commission). (2009). Executive summary of the status of the Indian Ocean swordfish resource. IOTC-2009-SC-04[E].

IOTC (Indian Ocean Tuna Commission). (2014). Report of the Twelve Session ofthe IOTC Working Party on Billfish. Yokohama, Japan, 21-25 Oktober 2014. IOTC2013-WPB12-R [E]: 102 pp.

Irianto, H.E., Wudianto., Suman, A., Susanto, K., Nugraha, B., Satria, F., \& Retnowati, S.D. (2014). Indonesia national report to the scientific committee of the Indian Ocean Tuna Commission 2014. IOTC-2014SC17-NR10, p. 23.

Irianto, H.E., Wudianto, Nugraha, B., Widodo, A.A., Satria, F., \& Sadiyah, L. (2014). Indonesia national report to the scientific committee of the Indian Ocean Tuna Commission 2015. IOTC-2015-SC18-NR10: p. 27.

Mahiswara \& Prisantoso, B. I. (2009). Billfish fisheries in Indonesia. IOTC-2009-WPB-14, p. 10.

Megalofonou, P., Dean, J.M., de Metrio, G., Wilson, C., \& Berkeley, S. (1995). Age and growth of juvenile swordfish, Xiphias gladius Linnaeus, from the Mediterranean Sea. Jour. Exp. Marine Bio. and Ecology. 188, 79-88.

Pauly, D. 1984. Fish Population Dynamics in Tropical waters: A Manual for Use with Programmable Calculators. ICLARM Studies and Reviews 8 :325 pp.

Pauly, D. (1990). Length-converted catch curves and the seasonal growth of fishes. Fishbyte. 3(3), 22-38.

Prager, M.H., Prince, E.D., \& Lee, D.W. (1995). Empirical length and weight conversion equations for blue marlin, white marlin and sailfish from the North Atlantic Ocean. Bulletin of Marine Science. 56(1), 201-210.

Punt, A.E., Huang, T.C., \& Maunder, M.N. (2013). Review of integrated size-structured models for stock assessment of hard-to-age crustacean and mollusc species. ICES Journal of Marine Science. 70(1), 1633.
Sadiyah, L., Dowling, N., \& Prisantoso, B.I. (2011). Changes in fishing pattern from surface to deep longline fishingby the Indonesian vessels operating in the Indian Ocean. Ind.Fis.Res.J. 17(2), 87-99.

Setyadji, B., Jatmiko, I., Wujdi, A., \& Nugraha, B. (2014). Preliminary analysis of length - weight relationship of swordfish (Xiphias gladius), black marlin (Makaira indica), and blue marlin (Makaira nigricans) caught by Indonesian longliners in the Indian Ocean. IOTC2014-WPB12-13: p. 12.

Sparre, P., \& Venema, S.C. (1999). Introduksi Pengkajian Stok Ikan Tropis. Buku 1. Manual. Terjemahan. Pus.Lit.Bang.Kan. Jakarta. p. 438.

Sun, C.L., Wang, S.P., \& Yeh, S.Z. (2010). Age and growth of the swordfish (Xiphias gladius L.) in the waters around Taiwan determined from anal-fin rays. Fish. Bull. 100, 822-835.

Tserpes, G., \& Tsimenides, N. (1995). Determination of age and growth of swordfish, Xiphias gladius L., 1758, in the Eastern Mediterranean using anal-fin spines. Fishery Bulletin. 93, 594-602.

Uchiyama, J.H., Skillman, R.A., Sampagna, J.D., \& DeMartini, E.E. (1998). A preliminary assessment of the use of hard parts to age central Pacific swordfish, Xiphias gladius. U.S. Dep. Commer. NOAATech. Rep. NMFS 142, 261-272.

Varghese, S.P., Vijayakumaran, K., Anrose, A., \& Mhatre, V.D. (2013). Biological aspect of swordfish, Xiphias gladius Linnaeus, 1758, caught during tuna longline survey in the Indian Seas. Turk. J. Fish. Aquat. Sci. 13, 529-540.

Wang, S.P. \& T. Nishida. 2010. Update of the application of an age-structured assessment model to swordfish (Xiphias gladius) in the Indian Ocean. IOTC-WPB-2010-13 : 16 pp.

Yabe, H., Ueyanagi, S., Kikawa, S., \& Watanabe, H. (1959). Study of the life history of swordfish (Xiphias gladius, L.). Rept. Nankai. Reg. Fish. Res. Lab. 10, 107-151.

Young, J., \& Drake, T. (2004). Age and growth of broadbill swordfish (Xiphias gladius) from Australian waters. Final Report for FRDC Project 2001/014: p. 121.

Yuniarti, A., Maslukah, L., \& Helmi, M. (2013). Studi variabilitas suhu permukaan laut berdasarkan citra satelit aqua MODIS tahun 2007-2011 di Perairan Selat Bali. Jurnal Oseanografi. 2(4), 416-421. 